\title{
類骨骨腫に対する低侵襲性手術
}

\author{
久留米大学医学部整形外科 \\ 森啓介・小宮 節 郎 \\ 平岡弘二・井上明生
}

\section{Percutaneous Excision of Osteoid Osteoma under X-ray Guidance}

\author{
Keisuke Mori, Setsuro Komiya, Koji Hiraoka \\ and Akio Inoue \\ Department of Orthopedic Surgery, Kurume University School of Medicine
}

\begin{abstract}
Two patients with osteoid osteoma treated by a percutaneous excision under a X-ray-guided technique are described. They include a 13-year-old boy with osteoid osteoma in the femoral neck and a 13-year-old boy with tumor in the tibia. After inserting a Kirschner-wire to the nidus under $\mathrm{X}$-ray guidance, a $7 \mathrm{~mm}$-diameter trephine needle was advanced through the wire. Nidus was successfully resected into a fan-shape without causing any problems, and no recurrence was seen. Our technique is simple, safe, and minimum to treat patients with osteoid osteoma.
\end{abstract}

Key words : osteoid osteoma (類骨骨腫), percutaneous excision (経皮的切除術), nidus (類骨中心), $\mathrm{X}$-ray guidance（透視下手術）

\section{はじめに}

類骨骨腫は下肢の長管骨に好発する良性骨腫瘍であ る. 治療においては nidus の完全摘出が必要である が，十分に摘出するため，必要以上の手術侵襲が加わ ることがある．今回我々は, イメージ下に生検針と電 気焼灼を用いた経皮的腫瘍摘出術を 2 例に施行し，良 好な結果を得たので報告する.

\section{症例}

症例 $1: 13$ 歳男性

主 訴: 左股関節痛

現病歴 : 1996 年 1 月頃より誘因無く左股関節痛出 現し, 近医にて保存的に治療するも疼痛が持続した。

翌年 2 月 1 日, 近医受診し左大腿骨䅡部骨腫瘍を指摘 され，2月 20 日，当科外来を受診した.

初診時所見 : 左股関節に安静時および運動時痛を認
め, 左股関節に屈曲 $90^{\circ}$, 内旋 $10^{\circ}$ の可動域制限を認 めた.

画像所見 : 単純 $\mathrm{X}$ 線では左大腿骨頚部内側に骨透亮 像を認めた（図 $1 \mathrm{a}$ ). CT では大腿骨頚部後内側に nidus と思われる所見を認め（図 $1 \mathrm{~b}$ )，MRI では coronal 像にて T1 強調像で low intensity, T2 強調 像で iso intensity，ガドリニゥム造影像にて周囲の み enhance される像を認めた（図 $1 \mathrm{c}$ )。臨床症状お よび画像所見より類骨骨腫と診断し，4月 10 日手術 を施行した.

手術方法 : 手術室にて毫引手術台を使用し, 仰臥位 にて手術を施行した. 皮店に小切開を加えてイメージ 下に nidusにカイドピンを刺入後, 骨皮質をドリル にて穿孔させガイドに沿って 7 ミリの東北大式生検針 をすすめ nidus を摘出した。 さらに周囲の骨硬化部 および反対側の骨皮質を trephine needle にて切除摘 出した (図 $1 \mathrm{~d})$. さらに同部に電気凝固用の wire を 


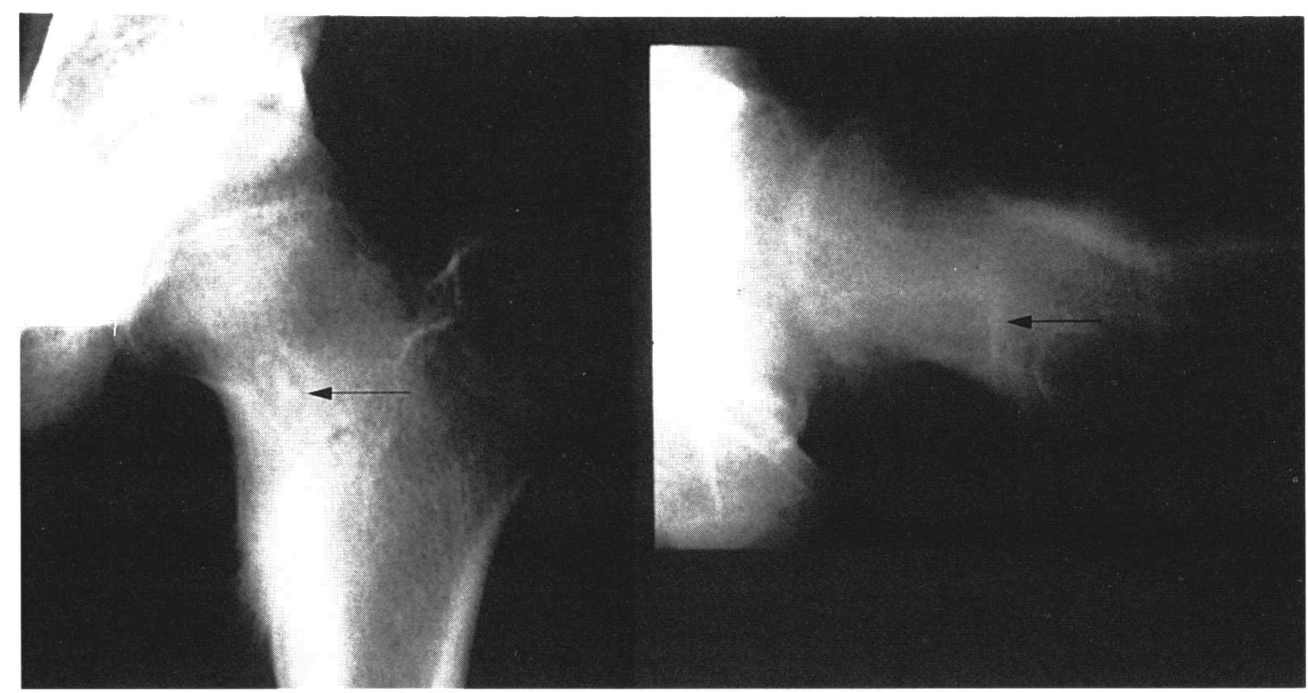

図 1 a 単純 X線像

左大腿骨頚部後内側部に骨透亮像を認める。

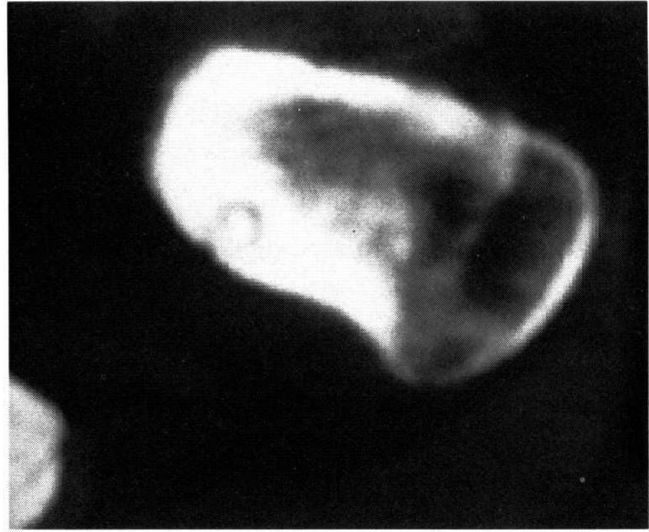

図 1 b CT 像

左大腿骨頚部後内側部に肥厚した骨皮質と その内部に骨透亮像を認める.

\section{進入し焼灼術を追加した。}

治療経過 : 術後左股関節痛消失し, 術後 3 週より部 分荷重訓練を開始し, 術後 1 年 3 力月の現在症状の再 発を認めていない。

症例 $2: 13$ 歳男性

主 訴: 左下腿の安静時痛

現病歴: 1997 年 1 月頃より左下腿部中央の夜間痛 を認めるようになり，5月頃より昼間の安静時痛を認
めた。 6 月 13 日，近医を受診し単純 X 線にて左脛骨 骨膜の肥厚を認めたため，7月 17 日，当科外来を受 診した.

画像所見 : 単純 X線では骨膜の肥厚と類円形の骨透 亮像を認めた（図 $2 \mathrm{a}$ )。CT では脛骨内に nidus と思 われる所見を認め, MRI では sagital 像にて, 脛骨の 後面に T1 強調像で low intensity, ガドリニウム造 影像にて，周囲が enhance される像を認めた。骨シ ンチでは同部の強い取り込み像を認めた（図 2 b). 臨床症状および画像所見から類骨骨腫と診断し，8月 20 日手術を施行した。

手術方法：イメージ下に trephine needle を使用し 経皮的腫瘍摘出術を施行した. nidus を含め周囲骨組 織を扇状に摘出できたため電気焼灼は施行しなかった (図 $2 \mathrm{c}$ ).

治療経過：術後より左下腿部痛消失し, 術後 3 週よ り部分荷重訓練開始し, 術後 11 力月の現在経過良好 である。

考察

類骨骨腫は良性の骨腫瘍であり, 典型的な単純 X線 所見は周囲に骨硬化像を伴う円形状の骨透亮像であり, これをnidus と呼んでいる。治療は nidus の摘出が 必要であるが, 術中にこの nidus を確認することが 


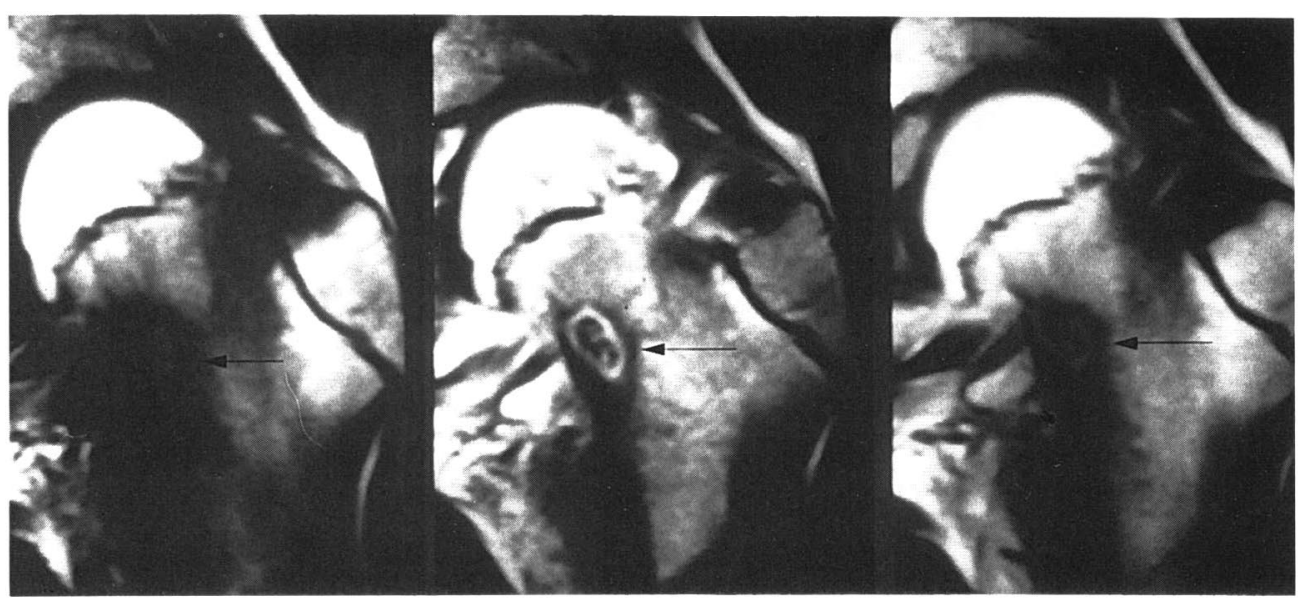

図 1 c MRI 像

(i) $\mid$ (ii) | (iii)

（i） T1 強調像：大腿骨頚部内側部に low intensity の area を認める.

(ii) GD- enhance 像: nidus 周囲が造影されている.

（iii） T2 強調像：同部位にわずかに high intensity 像を認める.

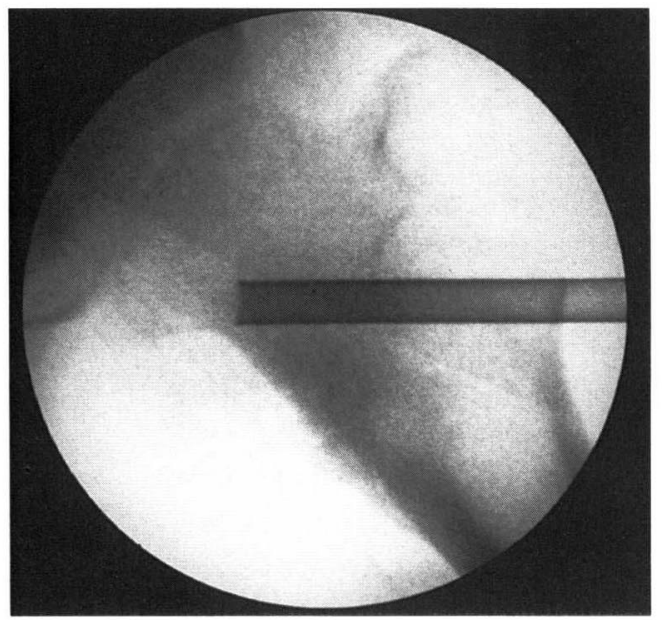

図 $1 d$ 東北大式生検針刺入時の Image 像

困難なことが多い、このため部位によっては必要以上 に手術創が大きくなり，周囲の健常骨組織まで切除す ることになり，大きな骨欠損部への骨移植が必要とな る場合がある. 今回我々はイメージ下に操作を行うこ とにより nidus の存在部位の把握と生検針を使用す ることでより少ない手術侵襲が可能と考え本手術方法
を選択した，過去に報告されている類骨骨腫における 経皮的腫瘍摘出術は CT ガイド下に施行されたものが

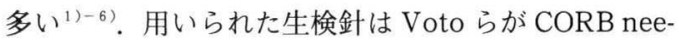
dle を使用 ${ }^{6)}$, 他に trephine needle ${ }^{4) 5)}$, drill resection system ${ }^{2) 3}$, cannulated drill ${ }^{1)}$ を使用した報告 を認め, 穴澤らはさらに焼灼法とアルコール注入を併 用している ${ }^{1)}$. 自験例における経皮的摘出方法では, 摘出部位によって CORB needle, trephine needle, 東北大式生検針を使い分けており, また清潔操作と麻 酔の危険性を考え手術室にてイメージ下に行っている. 電気焼灼法は病巣が扇状に周囲を含めて摘出できた 1 例には行っていないが, 病巣が最小範囲で摘出された 時には腫瘍細胞の残存の可能性もあり必要と考えてい る.

本手術法では手術侵襲が小さく清潔操作が可能であ り, 骨移植も不要であるが, 欠点としてレントゲン被 曝や病的骨折の発生の可能性があることである。また 過去に 1 例, 病巣の骨形成が著明で生検針による掻爬 が困難であり結果的にノミによる切除を余儀なくされ た症例を経験している. よって術前には摘出範囲の骨 硬化の程度を考慮し, 生検針によって掻爬可能から゙う か十分判断する必要があると考えられる. 


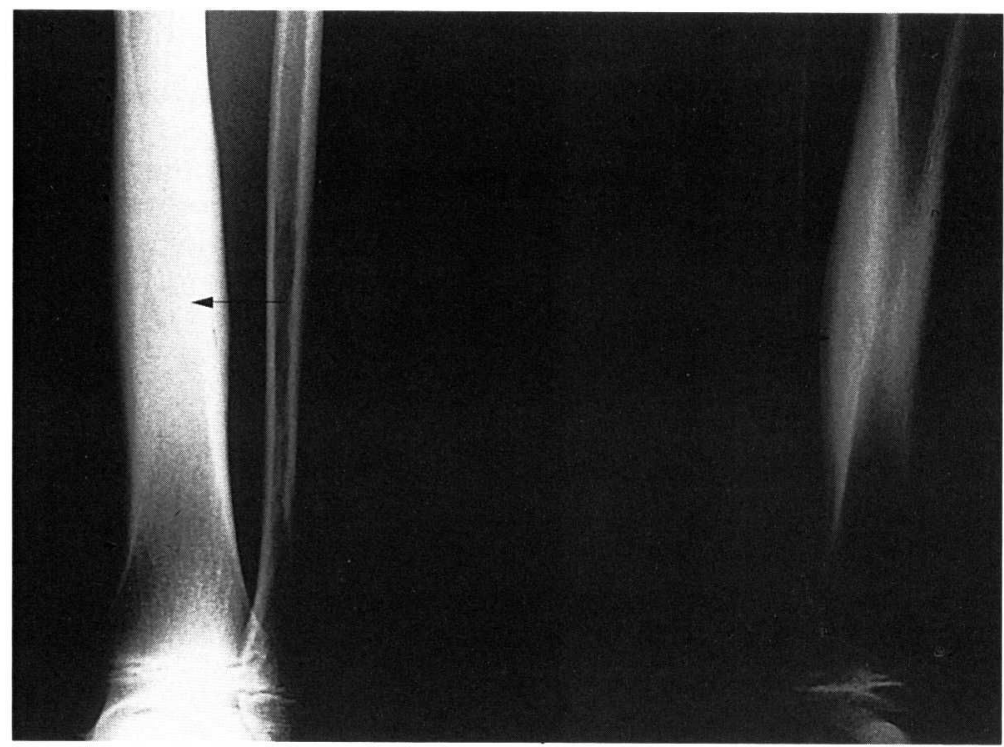

図 2 a 单純 $X$ 線像

左脛骨骨幹部に骨皮質の肥厚を認め，その内部に nidus を認める.
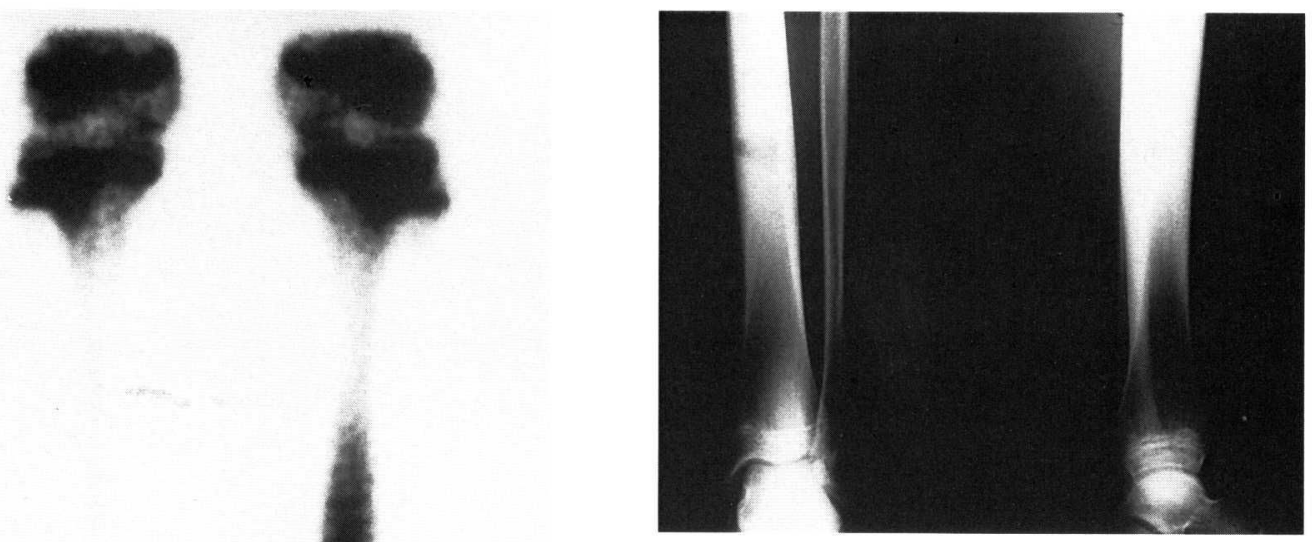

図 2 c 術後単純 X線像

腫瘍が扇状に切除されている像を認める。

$$
\text { ま と め }
$$

イメージ下の経皮的腫瘍摘出術および電気焼灼術の 併用は，類骨骨腫に対して有効であると考えられた。

\section{参 考 文 献}

図 2 b $99 \mathrm{mTC}$-scintigram 左脛骨骨幹部に集積像を認める.

1）穴澤卯圭ら：CT ガイド下に治療を行った類骨骨腫の 1 例 整形外科, 48 : 903-906, 1997. 
2) Assoun, J. et al. : Osteoid Osteoma : Percutaneous Resection with CT Guidance. Radiology 188 : 541 - 547 , 1993.

3) Baunin, C. et al. : Percutaneous Resection of Osteoid Osteoma under CT Guidance in eight Children. Pediatr. Radiol. 24 : 185-188, 1994.

4) Rosenthal, D. I. et al. : Osteoid Osteoma : Percutaneous Radio-Frequency Ablation. Radiology 197 : 451 -
454, 1995.

5) Towbin, R. et al. : Osteoid Osteoma : Percutaneous Excision Using a CT-Guided Coaxial Technique. Am. J. Roentgenal. 164 : 945-949, 1995.

6) Voto, S. J. et al. : Treatment of Osteoid Osteoma by Computed Tomography Guided Excision in the Pediatric Patient. J. Pediatr. Orthop. 10 : 510-513, 1990. 